\title{
Clarice com Teresa
}

\section{Clarice with Teresa}

\section{Clarice con Teresa}

\section{Clarice avec Thérèse}

\section{Gustavo Fujarra Carmona*}

Universidade Estadual do Rio de Janeiro - UERJ, Rio de Janeiro, Rio de Janeiro, Brasil

\section{Jean-Michel Vives**}

Université Nice-Sophia Antipolis - Unice, Nice, France

\begin{abstract}
RESUMO
Pretendemos com o presente artigo, revelar as possíveis convergências e divergências a respeito do caráter místico das obras de Clarice Lispector e de Santa Teresa d'Ávila. Para tanto, estabeleceremos um diálogo entre a obra e a vida destas duas autoras, além de trazer à discussão, os estudos de Lacan, Millot e Kristeva acerca da relação entre o gozo (outro) e a escritura. Acreditamos, deste modo, ser possível dar nova luz às suas obras e perceber como estas duas se correlacionam, no que diz respeito à dimensão mística de suas escrituras, na busca do Real e do Gozo Outro, cada uma, à sua maneira.
\end{abstract}

Palavras-chave: misticismo, Lispector, Ávila, gozo, escritura.

\begin{abstract}
We intend with this article, to show the possible convergences and divergences about the mystical character of the works of Clarice Lispector and Santa Teresa d'Avila. To do so, we will establish a dialogue between the work and life of these two authors, and bring to the discussion, studies of Lacan, Kristeva and Millot about the relation between the enjoyment (other) and the writing. We believe, therefore, be possible to give new light to their works and understand how these two authors correlate, in regard to the mystical dimension of their writings in search of Real and "Other Enjoyment", each in its own way.
\end{abstract}

Keywords: mysticism, Lispector, Ávila, joy, writing.

\section{RESUMEN}

Pretendemos con este artículo, mostrar las posibles convergencias y divergencias sobre el carácter místico de la obra de Clarice Lispector y Santa Teresa de Ávila. Para tanto, vamos a establecer un diálogo entre la obra y la vida de estos dos autores, y traer a la discusión, estudios de Lacan, Kristeva Millot y sobre la relación entre el gozo (otro) y la escritura. Creemos, por lo tanto, será posible dar nueva luz a sus obras y entender cómo estos dos 
correlatam, en lo que respecta a la dimensión mística de sus escrituras en busca del Real y del Gozo Otro, cada una a su manera.

Palabras clave: misticismo, Lispector, Ávila, gozo, escritura.

\section{RÉSUMÉ}

Nous nous proposons à l'occasion de cet article, de montrer les convergences et les divergences sur le caractère mystique des œuvres de Clarice Lispector et Sainte Thérèse d'Avila. Pour cela, nous allons établir un dialogue entre l'œuvre et la vie de ces deux auteurs, et apporter à la discussion des études de Lacan, de Kristeva et de Millot, sur la relation entre une certaine forme de jouissance (appelée Jouissance Autre par Lacan) et l'acte d'écriture. Nous croyons possible de donner une lumière neuve à ces œuvres et comprendre la corrélation entre ces deux auteurs, en ce qui concerne la dimension mystique de leur écriture dans la recherche du Réel et de la Jouissance Autre, chacune à sa manière.

Mots-clés: mysticisme, Lispector, Avila, jouissance Autre, écriture.

\section{Introdução}

"... engolia o corpo de Deus como quem sabe que engole o Mais, o Todo, o Incomensurável, por não acreditar na finitude me perdia no absoluto infinito..."

(Hilda Hilst)

Pretendemos com o presente artigo, revelar as possíveis convergências e divergências a respeito do caráter místico das obras de Clarice Lispector e de Santa Teresa d'Ávila.

Para tanto, estabeleceremos um diálogo entre a obra e a vida destas duas, colocando a obra de Clarice sob o "olhar" de Teresa, e, também, a de Teresa sob a "ótica" de Clarice.

\section{Bruxas ou santas?}

Muito foi discutido em torno do caráter hermético e "difícil" que envolve Clarice Lispector e suas obras, sempre perscrutando as profundezas do homem em busca da Coisa, das Ding, objeto a ${ }^{X 1}$ na linguagem lacaniana. Explicando, talvez, o lado mágico e subjetivo de sua literatura, disse Clarice Lispector certa vez: "Meu principal está sempre escondido. Sou implícita. E quando vou me explicar perco a úmida intimidade. Sou limitada apenas pela minha identidade. E sou assombrada pelos meus fantasmas, pelo que é místico, fantástico e gigantesco: a vida é sobrenatural."(Lispector, 1992, p.6)

Tamanho mistério e especulação, alimentados pela própria autora, seja através de suas declarações, seja através de seus trabalhos, por vezes inapreensíveis à razão menos atenta, atingem, finalmente, sua enésima potência, quando a escritora, não muito dada às entrevistas 
e apresentações, participa do I Congresso Mundial de Bruxaria, realizado em Bogotá, em 1975.

Seria Clarice mesmo uma bruxa? Poderíamos dizer, talvez, uma mística? Nas palavras de Ângela, personagem de Água viva, algumas pistas afirmativas: "Queimo em fogueira inquisitorial. Tenho o misticismo das trevas de um passado remoto. E saio dessas torturas de vítima com a marca indescritível que simboliza a vida". (Lispector, 1987, p.33)

Afinal, o que esconde a escritora que, ainda hoje, décadas após sua morte, atrai e enfeitiça multidões de novos leitores (fiéis) em todo o mundo?

O que há no caldeirão literário de Clarice, que faz de suas obraspoções, instrumentos tão poderosos e tocantes? Quais são as palavras mágicas necessárias para acessar essa dimensão do Real ${ }^{\times 2}$ que, por vezes, vislumbram as personagens da escritora (senão, a própria)? Como atingir a dimensão do gozo completo e infinito (Gozo Outro, gozo da morte em vida), o Graal de uma utópica plenitude? Como pegar "a Coisa" nas mãos?

Se voltarmos nossos olhos para Teresa d'Ávila, a Santa (por vezes profana e acusada de bruxa), as questões postas à baia não serão muito diferentes. Como esta grande mística e, também, escritora do século XVI, que balançou os alicerces da Igreja Católica, mais de uma vez interrogada e posta em questão pela Inquisição, atinge estas impossíveis esferas do Real com sua obra e seus escritos, repletos de opostos, metáforas, oximoros e antíteses, um verdadeiro rococó barroco ${ }^{\times 3}$, arrebanhando fiéis, quase cinco séculos depois de si?

\section{0 misticismo}

Afinal, o que é o misticismo? O que significa "ser místico"? Buscar a verdade absoluta? Atingir o real? Atingir o vazio... ou a plenitude? Atingir algum tipo de iluminação? Quiçá, ser tocado por Deus?

Trazendo a magia de Freud para a nossa reflexão, podemos dizer que, para ele, o misticismo seria simplesmente a "autopercepção obscura do reino do além do Eu, além da representação" (Freud como citado em Kristeva, 2008). O místico é aquele que ultrapassa a Lei... que vai além das regras, além da linguagem, além da metafísica, finalmente, além de si... E aquele provido de coragem para provar da maçã mística e ser expulso (expulsar a si mesmo) do paraíso da metafísica:

Eu caíra na tentação de ver, na tentação de saber e de sentir. Minha grandeza, à procura da grandeza do Deus, levara-me à grandeza do inferno. Eu não conseguia entender a Sua organização senão através do espasmo de uma exultação 
demoníaca. A curiosidade me expulsara do aconchego - e eu encontrava o Deus indiferente que é todo bom por que não é ruim nem bom, eu estava no seio de uma matéria que é a explosão indiferente de si mesma. A vida estava tendo a força de uma indiferença titânica. Uma titânica indiferença que está interessada em caminhar. E eu, que quisera caminhar com ela, ficara enganchada pelo prazer que me tornava apenas infernal. A tentação do prazer. A tentação é comer direto na fonte. A tentação é comer direto na lei. E o castigo é não querer mais parar de comer, e comer-se a si próprio que sou matéria igualmente comível. E eu procurava a danação como uma alegria. Eu procurava o mais orgíaco de mim mesma. Eu nunca mais repousaria: eu havia roubado o cavalo de caçada de um rei da alegria. Eu era agora pior do que eu mesma. (Lispector, 1998a, 96)

Os místicos são os exploradores de si e normalmente cultivam esse interior, o mais profundo, habitado pelo Todo Outro, até que o transformam em exterior, e o encobrimento e descobrimento tornamse, enfim, caminho. "O vazio explode em plenitude, a ausência em presença real, o sofrimento em gozo, a mortificação em delícia, o nada em êxtase, e reciprocamente... o espaço religioso enquanto cena amorosa... a mística fisga o real redesenhando a metafísica" (Kristeva, 2008, p.51).

E porque esta paixão pelo mundo místico??? Seria o corpo feminino o corpo negativo onde se abriga o vazio? Será o Gozo Infinito, "Gozo Outro" acessível somente às mulheres? Não necessariamente. Como afirma Lacan (1974) no seminário 20 - Mais, ainda (Encore), de 1972-1973, a ideia de "fêmea-vaso", corpo místico e corpo real, reunido pela arte... por uma representação infinitamente aberta dos corpos... Corpos dentro-fora, paradoxais e transitivos... esvaziadas esperando o encharcamento pelo Outro, também se dá em certos homens, como, por exemplo, em São João da Cruz.

De um lado, a presença de Santa Teresa: uma vida intrigante que se bate entre a difícil poda dos prazeres terrestres (celibato, anorexia, clausura e privações diversas), o trabalho incessante em prol do "próximo" (Outro), o esvaziamento completo de si mesma e o gozo infinito, através de uma união mística-carnal-imaginária com ninguém menos que Jesus, o Deus encarnado, o Pai-ideal, o Outro supremo... do outro lado, Clarice, cidadã do mundo, que na "simplicidade" cotidiana, no choque de si consigo mesma ou com uma simples barata (Paixão segundo G.H.) do mundo ao redor, goza com os simples "presentes" do presente, aberta ao devir e ao estranho e divino "Outro".

Caso as colocássemos sob as lentes do saber científico, diríamos, talvez, tratar-se de complicados casos de histeria, ou ainda, de 
psicose, não fossem suas escritas que, de alguma maneira, as legitimam, enquanto seres "aptos e sãos...", enquanto seres portadores de uma identidade (âncora) e de uma razão (leme) - fato paradoxal que reflete exatamente o oposto de suas escrituras "limite", "à deriva", mas, que, ao mesmo tempo, serve de álibi para que estas se mantenham firmes "em alto mar" - a (constante) construção de si e a escrita (incessante) se entre-sustentam, uma à outra.

\section{0 caminho da paixão}

Tal dimensão mística está diretamente ligada à dimensão do desejo, portanto, ao Gozo, mais especificamente, ao Gozo Outro, como supracitado.

Para nossas caras místicas, o desejo vai além da experiência ordinária e limitante da linguagem. Para Lacan, o homem será sempre um alienado... entrar num mundo regido pela linguagem é para o ser humano, entrar na lei regida pelo significante, que o mesmo chama de "a lei de lalangue", que desde seus primeiros passos, faz do ser humano um "zero à esquerda", sempre barrado pelo farol vermelho do significante... do Nome do Pai (Lacan, 2005, RSI).

"Ai de mim, que tenho infeliz corpo insatisfeito" (Lispector, 1999a, p.118) grita a personagem clariceana. Através do Outro, abre-se a possibilidade de sublimar as ilusões e dores causadas pelo inacessível Real, sempre velado coberto pelos limites da representação e da metafísica onto-teo-lógica...

É como se houvesse uma força (desejo) que almeja transpor os limites das ilusões representacionais que cercam a vida do homem. As escritoras querem o eu primeiro, o eu "original", aquilo que é velado e que nunca é possível alcançar plenamente através da linguagem (portanto uma busca impossível de se realizar plenamente em seu objetivo final), um retorno do logos ao mythos, à origem... Só através da linguagem artística, criadora, se mostra a única forma alcançável de vislumbre do "eu", ainda que sempre em tensão entre o que se mostra e o que se esconde.

Teresa num gozo sublime e religiosamente profano e secular... Lispector ávida por um prazer mundanamente divino... Ambas em busca do gozo pleno e infinito.

Qual seria então o trajeto para o "doce e doloroso" gozo infinito? Baseado na obra destas que aqui analisamos, parece-nos haver um caminho a ser trilhado que chamaremos "o caminho da paixão". Aceitar o trágico em suas vidas... sua incompletude.

O que chamamos de "o caminho da paixão", retrata a degeneração universal do homem e seu caráter trágico, Nietzsche reflete: aquele 
que "meditou até as últimas consequências sobre essa possibilidade, chegou a conhecer uma nova espécie de náusea - e também um novo dever!" (Nietzsche, 1992, p.117).

Aceitar a tragédia da existência é o primeiro passo para 0 autoconhecimento, para os subterrâneos do eu-estranho-interior. "Viver essa condição é a paixão, é a dor não como um acontecimento, mas como a própria natureza do homem" (Sá, 1979, p.258).

\section{0 deserto e a dor}

O caminho da paixão é um caminho solitário, um deserto silencioso:

aquela solidão inesperada. A solidão de uma pessoa que em vez de ser criada cria. Ali em pé no escuro, sucumbindo. A solidão do homem completo. A solidão da grande possibilidade de escolha. A solidão de ter que fabricar os seus próprios instrumentos. A solidão de já ter escolhido. E ter escolhido logo o irreparável: Deus". (Lispector, 1998, p.274).

Diferentemente da laica solidão mundana, na cidade grande, de Lispector, no caso religioso de Teresa, nota-se uma solidão paradoxal ou, poderíamos chamar, um paradoxo solipsista: o asceta sozinho NA união com Deus.

Após compreender a incapacidade da razão e da linguagem em captar o real, o homem se vê diante de um abismo, diante do vazio... deserto. É nesse deserto que a linguagem, "este membro cansado do corpo humano" (Barthes, 1994, p.19) se transfigura em ferramenta essencial na busca de uma "Vita Nova", da transformação.

A busca mística se dá através da suspensão das potências, o que quer dizer, do intelecto, da vontade e da imaginação escolástica... depois de atravessar a angústia e o "tumulto interior dos pensamentos", o entendimento torna-se "sente-entende-mento". "Ela ultrapassa a zona do entendimento comum para uma zona do pensamento sensível... um imaginário pensado, um pensamento sensível, o puro prazer das metamorfoses" (Kristeva, 2008, p.256).

"Sendo assim, a linguagem (psicossomática) torna-se, não mais instrumento da escrita, mas o próprio terreno do ato dito místico." (Kristeva, 2008, p.117).

Para "sentir" seu pensar, é preciso abandonar as pequenas e grandes posses do cotidiano... é preciso dar espaço e deixar-se vazio para receber todo o cosmos em si... nas palavras de Millot, "deixar o espírito livre, virgem como um recém-nascido", ideia consonante à filosofia que pregava Heidegger acerca da clareira e seu silêncio e do dasein. Um caminho sem retorno, que prioriza abolir todos os valores 
e signos identitários... "Elza é um nome como um saco vazio" (Lispector, 1992, p.15). O vazio da ausência é o espaço consagrado da arte... "Parece-lhe mais seguro, porque é caminho de cruz e contém em si um gosto de muito valor, a meu parecer, porque dele não participa o corpo, senão da pena somente e é a alma a que padece e goza sozinha do gozo e contento que dá este padecer" (Ávila, 2014a, p.126).

Entre a dor e o prazer de seu solitário "caminho da paixão", Teresa fantasia e goza: "A dor era tão intensa... Mas, ao mesmo tempo, a doçura causada por essa dor indizível tão excessiva que a única vontade era a de prolonga-la, e a alma não poderia então se contentar com qualquer coisa que menos do que o próprio Deus." (Ávila como em Kristeva, 2008, p.14).

Assim ela não tem nem mesmo tempo de sentir ou sofrer a dor da ausência... "em começando esta pena de que agora falo, parece que - Senhor arrebata a alma e a põe em êxtase, e assim não há lugar para ter pena nem padecer, porque vem logo o gozar." (Ávila, 2014a, p.195).

Nota-se nos seus textos a presença constante da ausência e do vazio. Uma espécie de niilismo. Ao pensarmos o niilismo, tomando o conceito de genealogia de empréstimo ao léxico nietzschiano, é possível notar que este segue-se, como abertura ao possível, a tarefa da criação de novos valores. Como observa Gerd Bornheim, a respeito de uma concepção dialética de crise, "a negatividade da crise (...) oferece em sua própria essência uma dimensão por assim dizer afirmativa, abrigada pela superação do negativo" (Bornheim, 2001, p.50), e da necessidade da fantasia e necessidade da (re) criação (de si e do mundo) a partir das cinzas de si mesmo.

O aspecto da ligação da pulsão de morte com a criação foi salientado por Lacan no Seminário 7, A ética da psicanálise, quando ele fala da criação ex nihilo, a criação oriunda do nada. A pulsão de morte é concebida por ele como "criacionista", na medida mesma em que, em sua tendência rumo ao zero absoluto de tensão, é igualmente promovedora da busca e da criação de algo radicalmente novo. A pulsão de morte exprime assim também, para Lacan, a busca de uma criação original que parte do zero e daí extrai toda a sua força. Ao mesmo tempo em que é "vontade de destruição", é "vontade de recomeçar com novos custos, vontade de Outra-coisa", e, mais essencialmente, "vontade de recomeçar a partir do nada" (Jorge, 2010a, p.137).

Reduzir-se ao nada, ser nada, não-ser, tornar-se simples objeto pulsional, é imperativo como base de uma poética do gozo. Chegar ao "vazio em que um homem se encontra quando vai criar. Desolado, ele provocara a grande solidão." (Lispector, 1999a, p.211). A personagem Ângela, do Último livro de Lispector, atenta para tal conduta: 
A despersonalização como a destituição do individual inútil - a perda de tudo o que se possa perder e, ainda assim, ser. Pouco a pouco tirar de si, com um esforço tão atento que não se sente a dor, tirar de si, como quem se livra da própria pele, as características (Lispector, 1998a, p.170).

O EU, segundo Lacan, porta em si mesmo o abandono e a morte imaginária. Os místicos são aqueles que são possuídos por uma estranha e poderosa aspiração de atingir esse abandono e essa morte.

Neste espaço abismal... o vazio, essa espécie de vaso ou janela, onde a clausura e o ilimitado, dentro e fora, bem e mal, ser e não ser, se interpenetram. Deste "furo", tomando o termo lacaniano, nasce a Arte, o desejo da escrita e da criação, para finalmente gozar.

\section{Deus, o Outro - Ek-stase}

No que diz respeito ao Outro, enquanto o Deus de Teresa se mostra divino, angelical e glorioso, ligado à religiosidade... o Deus de Clarice se chama Acaso, deus do devir, profano, laico e carnal, o deus que se mostra na bruxaria contida na vida cotidiana.

É preciso encontrar e atravessar o deserto, buscar no Outro o autoesvaziamento... um amor extasiante... ek-statico, que se realiza na perda de si... É preciso passar pela dor... chocar-se com o real e com o devir... uma purificação e expurgação completa para, enfim, gozar plenamente, uma experiência mística, diferentemente do gozo comum e limitado do significante (do sexo e de outros prazeres ordinários)... "O gozo e o deleite que o demónio dá é, a meu parecer, de maneira bem diferente. Poderá enganar com estes gostos a quem não tiver ou tenha tido outros de Deus" (d'Ávila, 2014a, p.163).

Quando escreve, Teresa diz não estar mais lá, ek-stática... autoanálise, constituições, recomendações, cartas, poemas, síncopes. Tomada pelo Outro, a escrita de Teresa é mentalmente e fisicamente incessante (Kristeva, 2008, p.31)... esgotamento e anulamento total de si e, por fim, o gozo.

Afinal, que gozo é este que advém do esvaziamento de si, que toma e extasia Teresa?

"Ditosa tal perda que é para se gozar mais do que nos parece se ter perdido; porque então se emprega a alma toda em amar a Quem o entendimento tem trabalhado por conhecer. Ama o que não compreendeu e goza do que não poderia tão bem gozar se não se fosse perdendo a si mesma para, como digo, mais ganhar" (Teresa, 2014a, p.141) 
Da mesma forma, Clarice, também desejosa de tal gozo pede o/ao Outro: "me dá tua mão" ... "dar a mão a alguém sempre foi o que esperei da alegria" (Lispector, 1998a, p.13).

Só fora de si será possível atingir o êxtase... ek-stase heideggeriano que promulga a morte do si (ego), em prol de uma existência plena com bases no devir, no aqui e no agora.

Teresa que diz... "o caminho é o sofrimento, o nada de tudo, isso tudo que não é nada... fora de você em você, fora de mim em mim, extasiástica, excêntrica"... O corpo machucado pelo desejo prova e significa sua união com o indizível... Lalangue. Com o Outro (Lacan) com a humanidade do Cristo... o caminho da paixão (Kristeva, 2008, p.50).

Clarice se esvazia então, como também faz Tereza: "Para ter chegado a isso eu abandonava a minha organização humana - para entrar nessa coisa monstruosa que é a minha neutralidade viva (Lispector, $1998 a$, p.94). Lucrécia, personagem de a cidade sitiada promulga: "o vazio é o pleno" (Lispector, 1995, p.183).

Do vazio, a partida para A dor, "mas uma dor que não era a que se evolava daqueles caminhos interrompidos e impossíveis - como as coisas caíam nelas próprias, tomavam-se verdadeiras, finalmente verdadeiras, oh Deus, Deus, socorrei-me. Era essa a sensação: oh Deus, socorrei-me." (Lispector, 1999, p.117).

Clarice roga agora ao Deus de Teresa... e goza:

"Voltada para dentro de mim, como um cego ausculta a própria atenção, pela primeira vez eu me sentia toda incumbida por um instinto. E estremeci de extremo gozo como se enfim eu estivesse atentando à grandeza de um instinto que era ruim, total e infinitamente doce - como se enfim eu experimentasse, e em mim mesma, uma grandeza maior do que eu." (Lispector, 1998a, p.49)

Como exposto acima, o corpo que goza através do Eros ${ }^{\times 4}$, também revela seu duplo inseparável, Thanatos, com o sofrimento e a morte. Na plenitude de um Janus, dor e prazer, inseparáveis, numa só face: "Ela atingiu um êxtase ao perder a multiplicidade ilusória das coisas do mundo e ao passar a sentir tudo como uno". (Lispector, 1999, p.122)

A dor e gozo, alicerces conjuntos na construção do imaginário místico... no Imaginário não há contradição nem impossibilidade... os opostos se unem em proposições contraditórias... finalmente se oferecendo como saberes impensáveis... dizeres indizíveis... visões do invisível.

Diante de tal postura, assume-se uma vida dupla... uma vida que se desenrola em dois planos diferentes ao mesmo tempo... é a 
coexistência destes dois mundos estranhos um ao outro, a união assumida, não tão de dois opostos, mas sim de dois incomensuráveis, que realiza o oximoro revelando imagens estarrecedoras, que apelam aos sentidos, visando o arrebatamento, o desequilíbrio, o movimento, o celebrar patético da inconstância, movimento perpétuo, eterna efemeridade.

As duas têm em comum esse senso do impossível, o que equivale a dizer, senso do Real, uma fidelidade intocável a esta impossível dimensão. Uma escrita, portanto, perigosa. Uma na clausura, no regime dos sentidos e nos textos religiosos, a outra no cotidiano, no dia-a-dia, no mundo, "campo-aberto", comum dos homens.

O mistério da experiência mística se dá na "certeza de ter tocado alguma coisa da dimensão do Real, alguma coisa de estranha a si mesmo, que se impõe como algo exterior" (Millot, 2006, p.54).

Catherine Millot ao pensar o "caminho místico", o compara a eclosão de um ovo. "O ovo é o mundo visível. A gema é o Amor, o Amor que é Deus, ele mesmo e que habita no fundo de todo ser humano, a princípio como um gérmen invisível. Quando a casca se rompe, quando ele sai dela, ele ainda tem por objeto esse mesmo mundo... mas que agora ele vê de fora da casca. Todo um infinito que se abre."

Assim a experiência mística é de certa maneira pontual e certeira, ao mesmo tempo que incompreensível. O paradoxo é aquilo que permite a sua apreensão: com ele o pensamento se vê diante de um abismo... o paradoxo leva em si o silêncio... há em si uma ascese, uma chave para adentrar a porta do sobrenatural... a chave para Deus, para a Coisa, Logoi alogoi... plenitude e vazio... presença e ausência, silêncio ensurdecedor, luminosidade tenebrosa...

Aqui não há sentir, senão gozar sem entender o que se goza: "Entende-se que se goza um bem, onde se encerram conjuntamente todos os bens, mas não se compreende que bem seja este. Todos os sentidos sentem este gozo, de modo que não fica nenhum desocupado para se poder empregar em outra coisa exterior ou interior" (Àvila, 2014, p.106).

\section{A escrita de si}

É claro para nós que a escritura, tanto para uma, como para outra destas figuras fascinantes, é parte essencial de seus caminhos. Há uma disciplina, uma ascese, uma experiência espiritual. A escrita impõe o esforço e a paciência, a renúncia em prol de um gozo absolto e sem demora... impossível de qualquer maneira.

A imobilidade inerte de certos estados, a chamada psicose, sofre de uma paixão, obediência servil, receptividade noturna que envolve expectativa mística, esfola-se então, rasgando-se a si mesmo, 
através do desapego, incluindo desprendimento, ou a queda (sem iniciativa ou consentimento) fora de si - todas estas situações, embora alguns estejam no limite do "conhecido", o que designa um lado oculto da humanidade que nós tentamos entender ao deixar pronunciar essa palavra desconsiderada: passividade "(Millot, 2006, p.140)".

A destituição de uma metafísica dualista, se mostra também no âmbito da linguagem: A presença das metáforas também se faz predominante na tentativa de cercar por todos os lados "a Coisa", na tentativa de captar a plenitude da dimensão do Real... o Gozo... "quase morta pelo êxtase do cansaço, iluminada de paixão, eu enfim encontrara o escrínio. E no escrínio, a faiscar de glória, o segredo escondido... Dentro do escrínio o segredo: Um pedaço de coisa." (Lispector, 1987, p.103).

$\mathrm{Na}$ escritura, predominância de oximoros, essa exuberante polimorfia da língua, imbatível contra o incansável vigilante do dualismo metafísico, sempre a condenar ou a aceitar, eterno descontentamento e ao mesmo tempo a pura vastidão de eterna receptividade.

Viver e criar dentro do trabalho de Clarice e de Teresa é, sempre, uma experiência limite. Apreciar suas obras também significa de certa maneira, andar à beira de abismos e labirintos. Ambas retratam uma enorme ruptura com a forma de representar comumente a realidade. "O universo semântico de seus textos extrapola os limites dicionarizados e aposta na construção de seus próprios referentes" (Rosembaum, 2002, p.21) o que permite que suas narrativas vaguem entre o mundo em si (Welt), "a verdade bruta" (Lispector, 1998a, p.18) e a representação (Umwelt):

"Eu era a imagem do que eu não era, e essa imagem do nãoser me cumulava toda: um dos modos mais fortes é ser negativamente. Como eu não sabia o que era, então "não ser" era a minha maior aproximação da verdade: pelo menos eu tinha o lado avesso: eu pelo menos tinha o "não", tinha o meu oposto. O meu bem eu não sabia qual era, então vivia com algum pré-fervor o que era o meu mal. E vivendo o meu "mal", eu vivia o lado avesso "(Lispector, 1998a, p.28).

O ócio diante da vida comum torna-se ascese e, por fim, escritura. Escrever advém da junção de várias vozes da ascese do "far-niente" radical com o trivial, visto de maneira diferente em relação ao Real. Assim escrever pode ser considerado a expressão do desejo de uma vida mais Real.

Para escrever tenho que me colocar no vazio. Neste vazio é que existo intuitivamente. Mas é um vazio terrivelmente perigoso: dele arranco sangue. Sou um escritor que tem medo da cilada das 
palavras: as palavras que digo escondem outras - quais? talvez as diga. Escrever é uma pedra lançada no poço fundo (9)... E grito: eu sinto, eu sofro, eu me alegro, eu me comovo. Só o meu enigma me interessa. Mais que tudo, me busco no meu grande vazio (34)... Fico à espreita de nada. O silêncio não é o vazio, é a plenitude (silencio, vazio, escuro, mudez) (Lispector, 1999, p.43).

\section{0 gozo}

Atingir essa dimensão do real é atingir algo de mítico. Na obra "o Solitude" Millot narra com uma beleza ímpar o evento: era como ter um vislumbre da origem do mundo, sua primeira manhã. Ver as coisas como se não tivéssemos nunca as visto, isso seria finalmente entrar no Real, como se o véu de Maia, utilizado por Schopenhauer em $O$ mundo como vontade e representação, fosse finalmente rompido. A realidade, que seria um mundo anterior, o mundo anterior a nós " (Millot, 2011, p.116).

Atingir um outro estado, onde o ser pensante se torna puro instinto animal, homem em sua nudez original. De acordo com Bataille, aceder a tal êxtase estaria mais ligado à selvageria que a uma paz interior... "os místicos evocam um afluxo de forças incomuns, uma energia sem tamanho. Diríamos quase, a lhes escutar, que Deus é um outro nome para a pulsão. (Millot, 2011, p.119).

Vive-se então num presente indefinido como o presente de um infante, com um grande vazio diante de si. A felicidade primitiva do pré-mundo, pré-discurso, pré-razão, pré-Eu.

O presente é a face hoje do Deus. O horror é que sabemos que é em vida mesmo que vemos Deus. E tudo isto é neste próprio instante, é no já. Mas ao mesmo tempo o instante atual é todo remoto por causa do tamanho-grandeza do Deus. Por causa do enorme tamanho perpétuo é que, mesmo o que existe já, é remoto: no próprio instante (Lispector, 1999, p.93).

O escritor (o artista) tem a capacidade de ir e vir entre esses estados de indiferenciação, onde o Eu se dissolve no espaço paradoxal da não dualidade, onde a diferença é abolida entre o interior e o exterior, proporcionando, assim, a ação criativa. Nesse espaço paradoxal, dentro e fora se interpenetram. Seja na clausura de Teresa ou no ilimitado cotidiano de Clarice, a solidão do infinito é lugar comum.

Uma espécie de vida não-dualista, segundo Jean Baruzi a experiência mística corresponde "a criação de um novo ser", ou ainda, "a liberação de um ser antes preso".

O abandono e o esfacelamento de si nos parece a princípio nos consumir por completo, nos atirar ao abismo... O abismo... essa 
imensidão que não podemos nomear, senão, Gozo... o gozo dos peixes que vivem e se movem em meio à agua. Elemento da fluidez, admirado e muito tratado nas obras das duas autoras

É preciso nos perdermos todos os dias... é preciso que a existência do ser seja estabelecida sobre o eixo de um grande Nada... Deus? Deus e Nada... uma dupla inseparável:

Ah! Que para ir além, é preciso dizer: Nada Nada! É por força de não ser nada que encontramos o infinito, uma vez que é Deus ... além de tudo o que é concebível ... Deus se funde no final com um grande vácuo que deixa-nos na pura natureza (Millot, 2006, p.42-43).

O ser desprovido de interioridade... simples médium do devir. Aceitar essa condição "passiva" diante do devir, submisso como um bloco de pedra, na qual o Escultor pode moldar e talhar segundo seu bel prazer.

O espaço se transforma de tal maneira, que dentro e fora se confundem e se transmutam de maneira contínua, abolindo assim qualquer dualidade.

Aí está o segredo. O ser se abre e não se fecha nem julga mais... seria a morte da alteridade??? Amor-fati: o ser, aqui, diz sim, sempre sim, sim a tudo... GOZO, em francês, JOUISSANCE... Je oui sens Eu-sim-sinto... a indiferença entre o bem e o mal, o prazer a dor, a luz e a escuridão é instaurada... a perfeição de ir "além" das dicotomias.

Como explicar este espaço perfeito? Tudo está lá quando não há nada. O vazio permite a possibilidade do tudo que se abre diante de si. O todo regido pelo "devir", face à face com a vida nua... "a vida toda nua é a vida perfeita. Pensamento escandaloso de quando estamos no inferno". (Millot, 2006, p.230)

Poderíamos dizer que se trata de uma escrita do abandono. Abandono de si, abandono metafísico de tudo que antes as delineavam enquanto sujeito. A troca entre a linha fechada que se encontra e delimita, pela linha reta e sem fim em direção ao horizonte.

O inconsciente penetra nas brechas na racionalidade clássica e opera com uma certa lógica contraditória que aponta para a experiência mística. O pensamento místico é recebido através do filtro próprio e único, que cada um recolhe em uma reflexão própria, que fica estocada e é penetrada através de seus próprio desejo... que o transforma e o faz sentir. Uma outra imaginação, psicossomática.

Como a metáfora do furo não simbólico da corrente barroca. Lacan discursa sobre essa relação entre o furo simbólico e o infinito na criação artística: "un trou a toujour quelque chose d'un siphon, d'un vortex, d'un maelströn. L'infini, peut-être, c'est la même chose vue 
sous um autre angle, une sorte de trou déroulé à I'horizontale et à perte de vue. L'infini aussi absorbe, aspire". (Lacan como citado em Millot, 2011, p.37).

A escritura tem papel fundamental no suporte de uma existência no "vazio". Todas essas imagens e histórias acabam por criar um novo tecido para recobrir o espaço onde se encontra o "furo".

Como diria Lacan: "a 'letra' aparece no espaço que antes era do desejo." Para Barthes o romance seria o sonho de uma nova vida. Romance é o nome do Absoluto. Uma escritura sacra, pois chamada a tomar o lugar de todos os desejos que o acaso (trauma, dor, nojo, ) vem de esvaziar. Por fim, a escritura torna-se o desejo único, o único que pode renascer da perda que se vem de sofrer, ou seja, a "saída pela/na/da escrita", além da ascese e do misticismo supracitados, também será um correlato que une as autoras analisadas neste artigo.

"Só há um desejo que valha a pena, o desejo do nome, da representação do sensível... os escritores sabem, eles podem saborear o gosto de se refazer em novo corpo através de um poema ou romance." (Kristeva, 2008, p.213).

A escrita do Gozo é sensível, metafórica, metamórfica... Escrito com o íntimo da alma, imaginação do corpo onde a carne se torna o verbo, enfim, ela é pré analítica: que a possibilidade de traduzir em imagem nomeável, em representação identificável, "a desordem inominável da visão passional só pode advir através do apaziguamento da violência sensorial." (Kristeva, 2008, p.254)

As escritoras acabam inventando uma terceira voz, onde o eu, atravessado pelo Outro, torna-se EU-Outro. Uma expiral dialética de inextinguível gozo: "Quando pudesse sentir plenamente o outro estaria salvo e pensaria: eis o meu porto de chegada." (Lispector, 1998, p.29).

Dar voz a essa terceira pessoa, encarnar, ser médium de seus atos e obras. Eternamente inclinada entre esses dois abismos. Paradoxal, barroca. "Não há paz ou descanso. A mesma mão que cura é a mesma mão que fere, portanto martírio sem fim, mil vezes eu morro, mil vezes eu renasço" (Kristeva, 2008, p.385).

Estou ainda semimergulhada nas sensações místicas. Bebi um pouco demais dessa forte bebida, fiquei um pouco embriagada. Nada contarei do que me aconteceu, pois, em vez de misticismo, podem falar que é mistificação. Ao mesmo tempo que eu recebia o Deus, eu estava toda pelo avesso e também sentia que além de Deus eu mesma fizera brotar em mim a crença vinda de minha escuridão medieval. E eu, flor trêmula. (Lispector, 1999, p.121) 
Seja o gozo eclesiástico de Teresa, seja o gozo cotidiano de Clarice, ambos refletem a arte como um exercício espiritual, que vai, principalmente, tematizar a noção de presença e de eventos. Uma ideia de presença, onde cada personagem carrega uma emoção poderosamente expressa.

Anne Juranville aponta 0 ato criativo como um momento de descoberta, que traz à tona uma revelação do impossível, que traz à tona o real através de uma nova forma significante. Para a autora, "penetrar o olhar" nesses pequenos "instantes da vida", mergulhar em tais profundezas seria o mesmo que abraçar de uma só vez o universo todo, o real.

O momento epifânico, ao contrário do modo como se dá a razão, se dá de maneira sensorial, é necessária a experiência, o ato empírico para atingir esse gozo, para sentir o absoluto.

Tal plenitude, advinda de um estado de vacuidade e do choque com o Outro, resulta na desconstrução simbólica dos personagens, que se reduzem a escombros, ao nada... ao Real, permitindo assim a criação... na dimensão do imaginário. Tal abertura ao desconhecido, "mais que um encontro amoroso, isso às vezes é um reencontro do destino, que produz alegria, êxtase, uma mutação, Iluminação, conversão" (Juranville, 2011, p.102).

\section{Considerações finais}

Ascese, escritura, busca pelo real e gozo... são algumas das descobertas aqui propostas, que correlacionam as duas místicas.

Teresa e Clarice afirmam o presente e "o choque com o momento chamado já" (Lispector, 1998a, p.74) aceitando a fluidez e o risco de "ser esmagada pelo acaso" (idem, p.11). Consequentemente, afirmam a mutabilidade e o movimento contínuo da identidade, pondo em questão antigos valores e necessidades metafísicas do homem, além da permanência da "carne infinita", utilizando sua narrativa como meio de resistência e ataque aos códigos sociais vigentes, as crenças onto-teo-lógicas do homem e suas pretensas "verdades".

Por fim, mergulhar nos labirintos destas duas, demanda aos seus leitores aventurar-se num estranho e novo mundo de ideias e sentimentos. Como se as próprias adentrassem a alma de cada um de seus leitores, inundando-os com seu fazer poético e seus modos de sentir os recônditos do homem e os convidando para compartilhar com elas de suas experiências místicas que vislumbram os segredos escondidos sob a grossa casca do cotidiano.

Percorrer suas obras significa tomar nas mãos o invisível, viajar no tempo e ainda descobrir o ser e o não-ser que habita dentro de cada um. Visualizar e viver esse entre-mundo é recriar-se, libertar-se: ser 
e estar. "Ah. Então termino atravessado pela voz de Deus e aqui digo como quem sopra leve: Ah... A gente nasceu para gozar" (Lispector, 1999, p.123)

\section{Referências}

Ávila, S. T. (2014). Livro das moradas ou castelo interior. Recuperado em 04/03/2014, http://www.documentacatholicaomnia.eu/03d/15151582,_Tere sa_d'Avila,_Moradas_Ou_Castelo_Interior,_PT.pdf

Ávila, S. T. (2014a). Livro da vida. Recuperado em 04/03/2014, http://www.documentacatholicaomnia.eu/03d/15151582,_Tere sa_d'Avila,_Livro_Da_Vida,_PT.pdf

Barthes, R.B. (1994). Roland Barthes by Roland Barthes. Los Angeles: UCLA PRESS.

Bornheim, G. (2001). Metafísica e finitude. São Paulo: Perspectiva.

D'ors, E. (1937). Du barroque. Paris: Gallimard.

Lacan, J. (1974). Le séminaire, Livre XX (1972 - 1973), Encore. Paris, Editions du Seuil.

Jorge, M. A. C. (2010a). Fundamentos da psicanálise de Freud e Lacan. Vol.2: a clínica da fantasia. Rio de Janeiro: Zahar.

Millot, C. (2006). La vie parfait. Paris: Gallimard.

Millot, C. (2011). La solitude. Paris: Gallimard.

Kristeva, J. (2008). Thérèse mon amour. Paris: Fayard.

Lacan, J. (2005). Les séminaires de Jacques Lacan, 1964-1979, XXII. Paris: Fayard.

Juranville, A. (2011). Lacan et la philosophie. Paris: PUF.

Lispector, C. (1987). Água viva. Rio de Janeiro: Nova Fronteira.

Lispector, C. (1992). Perto do coração selvagem. Rio de Janeiro: Francisco Alves Editora.

Lispector, C. (1995). A cidade sitiada. Rio de Janeiro: Rocco.

Lispector, C. (1998). A hora da estrela. Rio de Janeiro: Rocco.

Lispector, C. (1998a). A paixão segundo G.H. Rio de Janeiro: Rocco.

Lispector, C. (1999). O lustre. Rio de Janeiro: Rocco.

Lispector, C. (1999a). Um sopro de vida. Rio de Janeiro: Rocco.

Nietzsche, F. (1992). Além do bem e do mal: prelúdio a uma filosofia do futuro. Tradução, notas e posfácio Paulo César de Souza. São Paulo: Companhia das Letras.

Rosenbaum, Y. (2002). Folha explica - Clarice Lispector. São Paulo: Publifolha.

Sá, O. (1979). A escritura de Clarice Lispector. Petrópolis: Vozes; Lorena: Faculdades Integradas Santa Teresa d'Ávila.

Endereço para correspondência

Gustavo Fujarra Carmona 
Universidade do Estado do Rio de Janeiro - UERJ

Departamento de Letras - Literatura Comparada

Rua São Francisco Xavier, 524, Maracanã, CEP 20550-013, Rio de Janeiro - RJ, Brasil

Endereço eletrônico: myfriendgooo@yahoo.com

\section{Jean-Michel Vives}

Université Nice-Sophia Antipolis

Departamento de Psicologia

Faculté des Lettres, Arts et Sciences Humaines

98 bd Edouard Herriot - 06204 Nice, France

Endereço eletrônico: jeanmichelvives@gmail.com

Recebido em: 28/10/2014

Aceito para publicação: $13 / 11 / 2014$

\section{Notas}

* Doutorando em Literatura Comparada (Psicanálise e Filosofia). Universidade Estadual do Rio de Janeiro - UERJ. Pesquisador, Nice.

** Psychanalyste, Toulon. Professeur de Psychologie Clinique et Pathologique.

1 Objeto a está diretamente ligado ao Gozo Outro. Trata-se do objeto além da linguagem, o invisível, o ausente insubstituível que move o desejo. Deseja-se sem saber o que.

2 Em seu tratado de três registros, Real, Simbólico e Imaginário, RSI, o Real seria aquilo intocável à simbolização, "o real é o impossível", "não cessa de não se inscrever". Seu pensamento sobre o Real deriva primeiramente de três fontes: a ciência do real, de Meyerson, da Heterologia, de Bataille, e dos conceitos de realidade psíquica e de pulsão, de Freud. O Real toca naquilo que no sujeito é o "improdutivo", resto inassimilável, sua "parte maldita", o gozo, já que é "aquilo que não serve para nada". O Real, é aquilo que está fora do mundo (metafísifco), portanto, I-MUNDO. Se grande parte de sua obra foi marcada pelo signo de um retorno a Freud, Lacan considera o Real, junto com o Objeto a ("objeto ausente"), suas criações).

${ }^{3}$ Ao retomarmos aqui a noção do barroco, incursionamos pela obra du Baroque de Eugenio d'Ors. Sobre o barroco: 'há sempre um paradoxo... a coexistência de dois registros contraditórios em um mesmo membro, de duas direções opostas em um mesmo esquema, porém, uma dualidade de intenções, visto que o espírito que o dirige é um espírito em estado de ruptura interior, um espírito "quebrado" que guarda em si uma oposição (d'Ors, 1937, p.111).

${ }^{4}$ A reflexão sobre o erotismo, forma privilegiada das relações interpessoais, nasce com a civilização. Já em Platão está presente um dos aspectos mais fecundos da reflexão erótica: a função libertadora de eros, problema que foi retomado pela psicanálise ao descrever o seu aspecto libertador para o indivíduo. 